\title{
Amos 6:1-7 as an intensification of Amos 3:9-11
}

\author{
S.D. Snyman \\ Dept. of Old Testament \\ University of the Orange Free State \\ BLOEMFONTEIN
}

\begin{abstract}
The composition of the book of Amos has caused a lively discussion in which many different answers have been given. One of the many proposals, namely that of J. Jeremias, holds that Amos 3-4 (a (jotteswort) should be separated from Amos 5-6 (a Prophetenwort), with 3-t seen as representung an earlier stage in the formation of the book. In this contribution the proposal made by Jeremias is put to the test by examining two pericopes in Amos 3-6 i.e. 3:9-11 and 6:1-7. The result of the investigation leads to the conclusion that Amos 6:1-7 serves as an intensification of Amos 3:9-11. thereby confirming the results of Jeremias on the composition of the book of Amos.
\end{abstract}

\section{Introduction: views on the composition of the book of Amos}

The composition of the book of Amos has caused a lively discussion where many different answers have been given. A quick and cursory survey of recent hterature on the question of the composition of the book of Amos portrays a wide variety of conflicting viewpoints on this matter. Koch (1976a:81) in his study as well as Andersen and Freedman (1989:23-72) divide the book into four parts. Koch's option consists of Amos 1-2, 3-4, 5-9:6 and 9:7-15 while Andersen and Freedman distinguish the Book of Doom 1:1-4:13, the Book of Woes 5:1-6:14, the Book of Visions 7:1-9:6 and an Epilogue 9:7-15. According to Paul (1991:67) the book of Amos can be divided into five literary units: 1:2-2:16, 3:1-5:17, 5:18-6:1-7, 7:1-9:10 and 9:11-15. According to several scholars the book of Amos displays a three part structure. Smalley (1979:124-125) distinguishes three parts in the book: Amos 1-5:3, 5:4-15, 5:16-9:15. Stuart (1987:287) argues that Amos should be divided into a first group of oracles $1: 2-6: 14$, visions $7: 1-8: 3$ and a final group of oracles $8: 4-9: 15$. Another scholar who maintains a threefold composition of the book of Amos is Smith (1989:7-9): judgments on the nations, $1: 1-2: 14$, are followed by the verification of God's warnings of punishment on Samaria, 3:1-6:14, and finally 7:1-9:15 which deals with visions and exhortations of the end. According to Jeremias (1988a: 126, 1988b:218) the book of Amos can be divided into mainly three sections: a middle part containing the words of Amos 
and characterised by the saying "hear this word" (chapters 3-6), surrounded by two other parts, the oracles against the nations or Völkerworte at the beginning of the book (chapters 1-2) and the vision reports or Visionsberichie at the end of the book (chapters 7-9). Van der Wal (1983) argues for a two part division in the book, the first part consisting of chapters 1-6 and the second part consisting of chapters 7-9. Little wonder then that Hasel (1991:95) in a recent publication on the book of Amos concluded that the compositional picture of Amos in current scholarship is anything but unified.

\section{Problem statement}

The aim of this contribution is to focus on only one of the many proposals on the composition of the book of Amos by putting the views of Jeremias to the test by examining in more detail two pericopes in Amos 3-6 and to establish whether his thesis would be valid in a particular case in Amos 3-6. The two pericopes under discussion are Amos 3:9-11 and 6:1-7. On the matter of method Jeremias (1988b:218) is of opinion that synchronic questions pertaining to the surface of the text must be bound together with diachronic questions about the individual stages through which the book passed before attaining its final form. This contribution will follow these methodological guidelines by subjecting the two pericopes under discussion to a structural analysis and also to pay attention to matters such as Gattung, Sitz im Leben and redactional issues.

\section{The views of J. Jeremias on the composition of Amos 3-6}

In the above-mentioned article Jeremias (1988a:131) calls for a closer examination of Amos 3-6. He notes that the introductory verses beginning with "hear this word" in 3:1, 4:1 and 5:1 are not in. each case exactly the same. According to him "hear this word" in $4: 1$ should be taken as an introduction to only $4: 1-3$ : on the one hand it lacks the relative clause characteristic of $3: 1$ and $5: 1$ and on the other hand it is directed spesifically to the wealthy women of Samaria over against 3:1 and 5:1 with a more general address. A closer examination of $3: 1$ and $5: 1$ also brings significant differences to the fore. In $3: 1$ it is a word from Yahweh

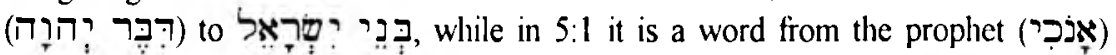

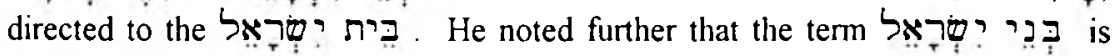
used throughout Amos 3-4 as a designation for the people of God while the term

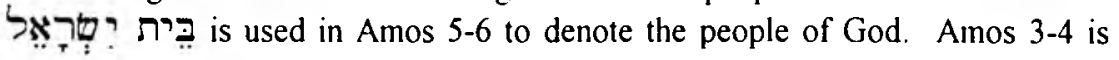
thus clearly a Gotteswort followed by a Prophetenwort in Amos 5-6. These observations lead Jeremias to the conclusion that Amos 3-4 should be distinguished from Amos 5-6, as 3-4 represents an earlier stage in the formation of the book. Yet, in spite of the separation of Amos 3-6 into two parts the Zusammenhang of these parts must also be recognised (Jeremias, 1988a:135). The conclusion Jeremias reaches is that the tradents of Amos's words did two things simultaneously. On 
the one hand they sharpened Amos's accusations, extending them to all Israel, and brought them into confrontation with Yahweh's saving acts. On the other hand, they dared to call people to a new beginning in the establishment of justice even more clearly than Amos dared to do (Jeremias, 1988a:136; Jeremias, 1988b:227).

\section{A structural analysis of Amos 3:9-11 and Amos 6:1-7}

\section{- Amos 3:9-11}

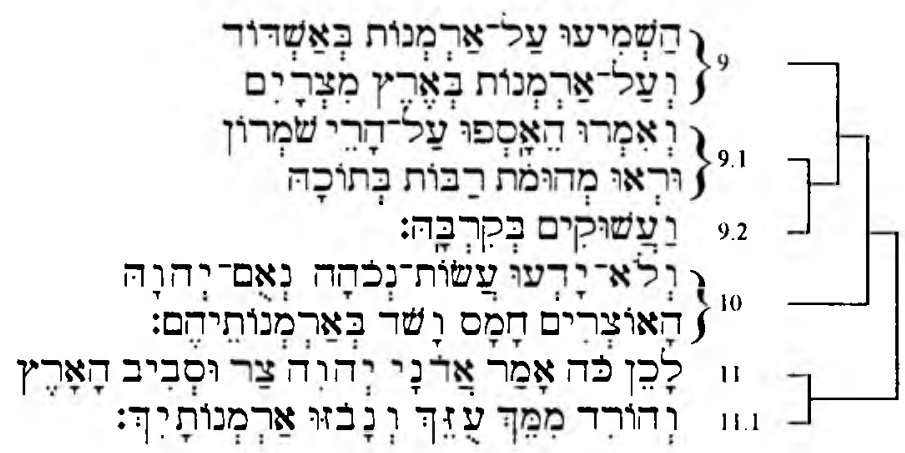

Amos 3:9-11 is a well demarcated pericope (cf. also Gitay, 1980). It begins with הַשְׁמִ (cf. also Amos 3:1, 3:13,4:1, 5:1 and 8:4) indicating the beginning of a new unit in the book. אַ: is found in stichoi 9-11.1 (verses 9, 10 and 11) which is another indication of the limits of the particular pericope as it is not

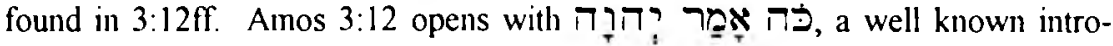
ductory formula indicating the beginning of another pericope

Stich 9.1 and 9.2 (verse 9) are linked because of the waw copulative in 9.2 and

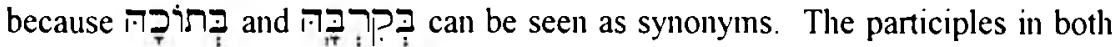
9.1 and 9.2 also call for the linkage of stich 9.1 with stich 9.2 . The waw at the beginning of stich 9.1 and the imperatives found in stich 9 and 9.1 are indications that stichoi 9 and 9.1-9.2 (verse 9) must be joined. Stichoi 9, 9.1 and 9.2 link with stich 10 (verse 10) due to the waw beginning of stich 10 (verse 10). in stich 10 (verse 10) also brings the divine utterance of stichoi 9-10 (verses 9-10) to an end.

The waw at the beginning of stich 11.1 (verse 11) continuing the utterance in stich 11 (verse 11) necessitates the joining of stich 11.1 with stich 11 (verse 11). The word at the beginning of stich 11 (verse 11 ) - לְ -indicates that a conclusion is drawn on the basis of the foregoing argumentation and 
therefore stichoi 9-10 and 11-11.1 are interlinked. אָרמ: is found in stichoi 9, 10 and 11 , binding the stichoi together in a unity.

- Amos 6: 1-7

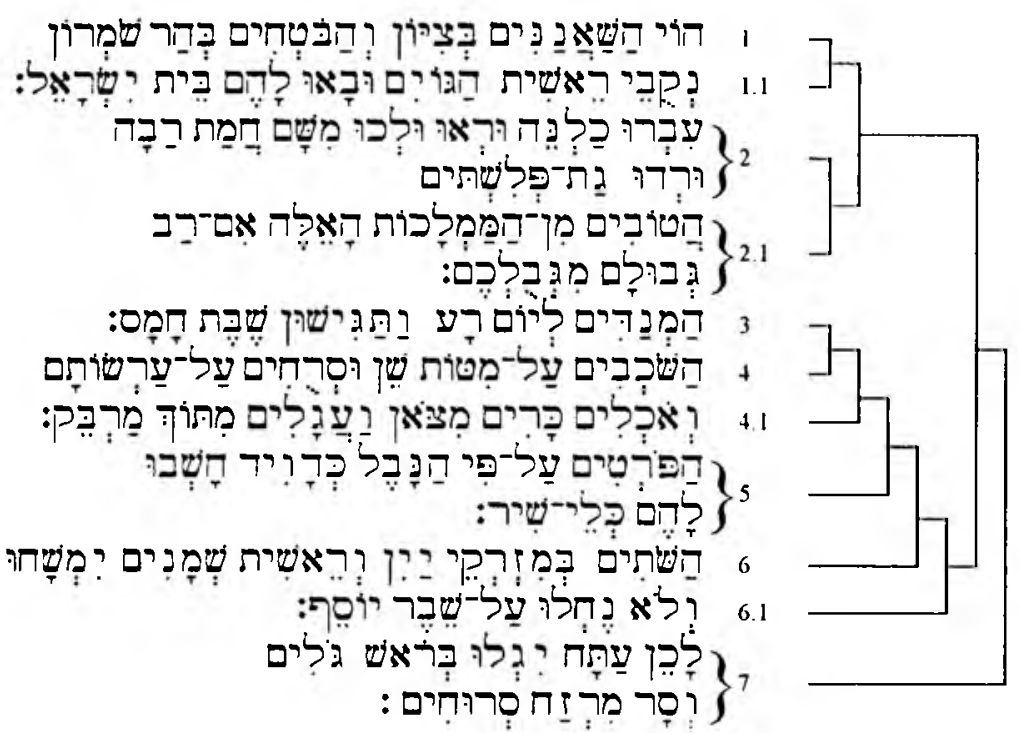

There is little doubt that Amos 6:1-7 constitutes a denarcated pericope. The call in verse 1 (stich 1) marks the begimning of a new pericope and as in the case in Amos 3:9-11, לָ denotes the idea of a conclusion reached on the basis of a

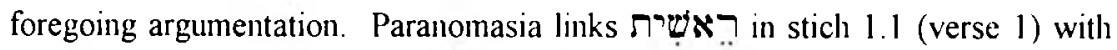

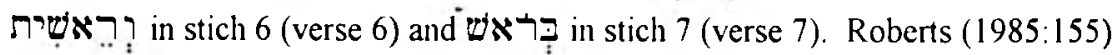
makes the remark concening the demarcation of Amos 6:1-7 that there is a fairly general agreement on the extent of the oracle.

Stichoi 1 and 1.1 link because of the participles common to both stichoi. Stichoi 2 and 2.1 link because of the imperative fonns found in both stichoi. Stichoi 1-2 (verses 1-2) should be grouped together. The many proper names occurring only in stichoi 1-2 point to the linkage of verses $1-2$. The reference to kingdoms

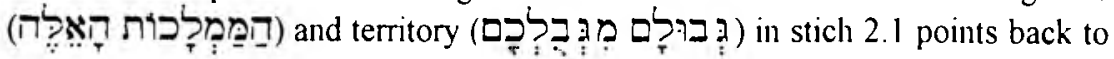
the foreign cities mentioned in stich 2 as well as Zion and Samaria in stich 1 which serves as another argument in favour of the linkage of stichoi 1-2 (verses $1-2)$.

Stich 3 (verse 3) introduces a new unit in Amos 6:1-7. No further mention of foreign cities and no more plural imperative forms - characteristic of stichoi 2-2.1 (verse 2) - are found from stich 3 onwards. Stichoi 3-6.1 (verses 3-6) are further 
characterised by a number of participles altemating with finite verbs - a phenomenon which is an indicator that these stichoi should be joined. Paronomasia links שִֶֶׁ in stich 6.1 (verse 6) with stich 3 (verse 3) acting at the same time as an inclusio (Carroll, 1992:262) providing yet another argument for the joining of stichoi 3-6.1 (verses 3-6). Carroll (1992:258) also notes that the perspective changes in verse 3 from Israel's relations with foreign powers to that of internal affairs.

Stichoi 1-2.1 (verses 1-2) are interlinked with stichoi 3-6. I (verses 3-6) due to the flow of the argument presented in the pericope and because of the continuation of participle forms in both parts.

There is almost general agreement that stich 7 (verse 7) constitutes the third part

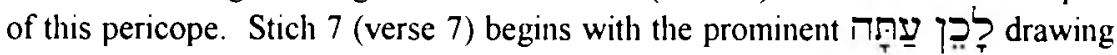
the pericope to a conclusion by introducing the verdict pronounced upon the people. Ultimately stich 7 (verse 7) links up with stichoi 1-6 (verse 1-6).

\section{Amos 3:9-11 and 6:1-7 related}

Following the thesis of Jeremias, Amos 3-4 and 5-6 can and even should be related to each other. There are indeed several arguments pointing in the direction of a relationship between Amos 3:9-11 and 6:1-7.

Jeremias himself (1988a:135; 1988b:225) noted that the enumeration of the transgressions in the capital city of Samaria combines the divine speech of chapters 3-4 and the prophetic speech of chapters 5-6.

The results of a structural analysis reveal that both pericopes display a similar structure. In each case the pericope consists of three parts. In Amos 3:9 mention is made of foreign cities followed by the actual accusation in Amos 3:10 and finally the pericope concludes by the verdict pronounced upon the guilty party in verse 11. In Amos 6:1-7 the pericope also commences with a reference to foreign cities (in verses 1-2). This reference is also followed by the actual accusation (in verses 3-6) and the pericope comes to a close (in verse 7) by the verdict intro-

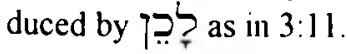

It has already been referred to that in both cases foreign cities are mentioned. In Amos 3:9 the foreign city of Ashdod is mentioned as well as Egypt while in Amos 6:2 the foreign cities of Calneh, Hamath and Gath are mentioned. Both Gath and Ashdod are Philistine cities.

There is, however, an important difference between the mentioning of the cities which should also be kept in mind. In Amos 3:9 the cities are called upon to come and look at Samaria while in Amos 6:2 Samaria and Zion are called upon to look at the foreign cities. Carroll (1992:256) rightfully remarks that the idea of 
going to another country (in Amos 6:2) is reminiscent of Amos 3:9 but that the difference in purpose could not be greater. In 3:9 the pagan nations come to bear witness to the sin and observe the judgment on the people, while Israel's leaders in $6: 2$ attempt to bolster their pride and in doing this confirm themselves in that $\sin$.

In both cases the sin of which Samaria (and Zion in Amos 6:3) is accused of is described with the same word: ${ }_{0} \prod_{\tau}$. In Amos 3:10 the inhabitants of Samaria are accused of the violent way in which they acquire their wealth ("filling their mansions with things taken by crime and violence" - Good News Bible). In Amos 6:3 they are accused of "bringing near the throne/rule of violence" (Wittenberg, 1987:57). It should also be noted that Amos 3:10 and 6:3 are the only two instances where the word ${ }_{T} \prod_{\Gamma}$ occurs in the book of Amos. This observation has lead several scholars to allude to a possible relation between Amos 3:9-11 and 6:1-7 (Wolff, 1975:320; Wolff, 1977:275; Mays, 1976:116-117; Carroll, 1992:258; Van Gelderen, 1933:164).

The verdict is in both cases introduced by דָָ - cf. Amos 3:11 and Amos 6:7 (Cripps, 1969:208; Koch, 1976b:185; Limburg, 1988:112). In both cases the verdict pronounced upon them hints back on what they are accused of. In Amos 3:11 mention is made of their mansions which will be destroyed. In Amos 3:10 they are accused of filling their mansions with things taken by crime and violence. In Amos 6:7 it is predicted that their feasts and banquets will come to an end (סָר שרחים was also mentioned in verse 4), while in Amos 6:4-5 they are accused of feasting and of composing songs.

To sum up the first part of the argument: There are a number of indications that Amos 3:9-11 and 6:1-7 can be linked; the enumeration of transgressions conducted in the capital city of Samaria mentioned in both pericopes, the similar structure of both pericopes, the foreign cities mentioned in each of the pericopes, the occurrence of verdict introduced by לָָָ all point to a link between Amos 3:9-11 and 6:1-7.

\section{Amos 6:1-7 as an intensification of Amos 3:9-11}

\subsection{The accused}

In Amos 3:9-11 only Samaria is addressed while in Amos 6:1-7 it is not only Samaria which is addressed, but also Zion - more so, Zion is mentioned in a prominent and initial position right at the beginning of the oracle. It strikes one as rather surprising that Zion is also included in the woe-oracle as Amos directs his prophecies mainly to Israel, the northern kingdom, and not to Judah. Yet, in this case Zion is explicitly mentioned. This observation fits in with the conclusion 
Jeremias (1988a:136; 1988b:227) reached that the tradents of Amos's words sharpened the accusations of Amos and at the same time also extended them to all Israel. Although some scholars (Wolff, 1977:269-270; Deissler, 1981:119; Markert, 1977:164) hold the reference to Zion to be a later addition to the book and others (Rudolph, 1971:215) emend the text albeit with no textual evidence, there are many scholars (Harper, 1960:143; Cripps, 1969:202; Mays, 1976:115; Koch, 1976b:184, Deissler, 1981:119; Roberts, 1985:157; Van Leeuwen, 1985:237, Stuart, 1987:358, Limburg, 1988:110) who regard this reading as the orginal - especially due to the reference to David in verse 5 . The consequence of Jeremias' point of view is that not only the reference to Zion should be taken as a later addition to the book, but that the whole of Amos 6:1-7 represents a later edition.

The intensification is obvious: the intensification is implied in the fact that not only Samaria is included in the woe-oracle but, contrary to what one would expect, Zion as well. The span of the prophet's judgement is thus widened by the tradents of Amos's initial words to include not only Israel but Zion as well.

\subsection{The word $\underset{T}{\prod_{T}}$}

As was noted, the word 3:10 and Amos 6:3. In Amos 3:10 the meaning of "acquiring wealth and property by the exploiting of others," cf. especially verse 10.

In Anos 6:3 the people are accused of dismissing the day of disaster and bringing near the seat/throne of violence - being the reason for the announced woe in verse 1 . The meaning of this is elaborated on in verses $4-6$ by the use of $\mathbf{Z}+$ participles. The great number of participles in verses 3-6 have long been recognised by scholars (Markert, 1977:167-168; Wolff, 1964:13; Wolff, 1977:273; Andersen \& Freedinan, 1989:548, 557). The use of the participle plus $\square$ has inter alia the function of relative clauses (Waltke \& O'Comır, 1990:621; Gemser, 1968:225) so that verses $4-6$ can be understood as a closer definition and clarification of what is actually meant by the people (verses 3-6a) without any regard to the plight of Joseph (verse 6b) is sharply criticised and is rendered as nothing else but violence. It is their conduct and attitude of indifference coupled with a luxuriant lifestyle which are labelled as violent.

While specific and elaborate meaning in 4-6. It is also significant that the $\sin$ of the people is described by the word acquired but also the way in which it was enjoyed with no concem for the demise of Joseph are judged by the prophet. 


\subsection{The Gattung employed}

The Gattung employed in these two pericopes also indicates an intensification in Amos 6:1-7. The Gattung used in Amos 3:9-11 is usually described as a Prophetenspruch or a Scheltwort (Weiser, 1974:146; Kaiser, 1985:302) or a Prophetische Gerichtswort (Wolff, 1977:191, Koch, 1976a:133) or Gerichtsrede (Van Leeuwen, 1985:122). In Amos 6:1-7 the Gattung of the Weheruf or woeoracle is employed (Kaiser, 1985:302; Wolff, 1977:273; Rudolph, 1971:218; Van Leeuwen, 1985:236; Andersen \& Freedman, 1989:545, Deissler, 1981:119; Mays, 1976:114; Koch, 1976b:185, Markert, 1977:170). Whereas the Prophetenspruch indicates punishment, the woe-oracle indicates more than punishment, it indicates death, the Sitz im Leben of the woe being rooted in the funeral lament and practices in Israel (Gerstenberger, 1962; Clifford, 1966; Wanke, 1966, Krause, 1973; Janzen, 1972). Jeremias remarks that the dominant theme of Amos 5-6 is that of death (Jeremias, 1988a:134; 1988b:224).

\subsection{The content of the judgement pronounced}

The judgement pronounced upon the people in Amos 3:11 holds that an (unnamed) enemy will surround the land and that their palaces or strongholds will be devastated. In Amos 6:7 exile is predicted: not only their palaces will be destroyed but they will be taken captive, which ultimately means the loss of the land promised to them by Yahweh himself.

In Amos 3:11 the rich people only stand to lose their palaces. No mention is made of the loss of people. In Amos 6:7 people are involved: they will be taken into exile.

In Aunos 3:11 it is only those who live in their palaces who will be punished. In Amos $6: 7$ it is not only the affluent people who will go into exile, they will merely lead the whole nation of Israel into exile.

\section{Conclusion}

From this preliminary investigation it seems as if the view of Jeremias on the composition of Amos 3-6 at least deserves serious consideration and calls for an even more detailed analysis of the whole of Amos 3-6. When applied to Amos 3:9-11 and 6:1-7 it seems as if his thoughts on the composition of Amos 3-6 hold valid. The inclusion of Zion in the woe-oracle of Amos 6:1-7 which has always been a crux interpretum, is explained in a more satisfactory manner, the sin of דָד only mentioned in Amos 3:10 is given a more elaborate meaning in 6:1-7, the Gattung of the woe employed in Amos 6:1-7 also indicates a sharpening (to 
use the words of Jeremias) of the message of Amos 3-4 and the final verdict of $6: 1-7$ is much more severe than the verdict pronounced in $3: 11$.

An investigation of this kind also brings something else to the fore. Different pericopes or units in the books of the Old Testament should not merely be analysed and interpreted in isolation from each other. To investigate the possible relationship between different units in a particular book may prove to be a fruitful way of gaining a better understanding of the particular book and its theological trends.

\section{Bibliography}

ANDERSEN, F I \& FREEDMAN, DN. 1989. Amos A New Translation with Introduction and Commentary. New York : Doubleday. (Anchor Bible)

BUTLER, J T., CONRAD, E.W \& OLLENBURGER B.C., eds. 1985 Understanding the Word, Essays in Honor of B W Anderson. Sheffield : JSOT (JSOT Supplement 37)

CARROLL, MD. 1992. Contexts for Amos. Prophetic Poetics in Latin American Perspective Sheffield: JSOT (JSOT Supplement Series 132)

CLIFFORD. RJ 1966 The Use of Hòy in the Prophets. Catholic Biblical Quarterly; 28 458-464

CRIPPS, R S 1969 A Critical \& Exegetical Commentary on the Book of Amos, the Text of the Revised Version edited with introduction, notes \& excursuses London SPCK

DEISSLER, A 1981. Zwolf Propheten Hosea Joel Amos. Wurzburg : Echter Verlag

GEMSER, B 1968 Hebreeuse spraakkuns Pretoria : Van Schaik

GERSTENBERGER, E 1962 The Woe-oracles of the Prophets Journal of Biblical literature, 81:249-263

GITAY, Y. 1980 A Study of Amos's Art of Speech_A Rhetorical Analysis of Amos 3:1-15 Catholic Biblical Quarterly, 42(3) 293-309

HARPER, W.R 1960. A Critical and Exegetical Commentary on Amos and Hosea Edinburgh : T \& T Clark. (ICC)

HASEL, GF 1991. Understanding the Book of Amos, Basic Issues in Current Interpretations. Grand Rapids : Baker Book House

JANZEN, W 1972 Mourning Cry and Woe Oracle. Berlin : Walter de Gruyter (BZAW 125.)

JEREMIAS, J 1988a. Amos 3-6 Beobachtungen zur Entstehungsgeschichte eines Prophetenbuches. Zeitschrift finr die alliestamenl/iche Wissenschaft, 100 (Supplement): 123 138 .

JEREMIAS, J 1988b Amos 3-6: From the Oral Word to the Text (In Tucker, GM, Peterson, D L \& Wilson, R R eds. Canon, Theology and Old Testament Interpretation Essays in honor of Brevard S Childs. Philadelphia : Fortress p 217-229.)

KAISER, O 1985. Einleitung in das Alte Testament Gütersloh : Gütersloher Verlagshaus

KOCH, K 1976a Amos, Teil 2 Synthese Neukirchen-Vluyn : Neukirchener Verlag

KOCH, K 1976b Amos, Teil 3 Schlüssel Neukirchen-Vluyn : Neukirchener Verlag.

KRAUSE, H J 1973. hôj als prophetische Leichenklage uber das eigene Volk im 8 Jahrhundert Zeitschrift fïr die altrestamentliche Wissenschaft, 85(1): 15-46

LIMBURG, J 1988 Hosea-Micah Atlanta : John Knox. (Interpretation)

MARKERT, L 1977. Struktur und Bezeichnung des Scheltworts Eine gattungskritische Studie anhand des Amosbuches Berlin: Walter de Gruyter. (BZAW 140)

MAYS, J.L 1976 Amos, a Commentary London: SCM

PAUL, S. 1991. Amos: A Commentary on the Book of Amos. Minneapolis : Fortess 
ROBERTS, JJM 1985. Amos 6:1-7. (In Butler, J T. Conrad, EW \& Ollenburger, B.C., eds. Understanding the Word, Essays in Honor of B W Anderson. Sheffield : JSOT p. 155-166 (JSOT Supplement 37)

RUDOLPH, W. 1971. Joel Amos Obadja Jona. Gerd Mohn: Gutersloher Verlagshaus (KAT XIII/2)

SMALLEY, W.A 1979. Recursion Patterns and the Sectioning of Amos The Bible Translalor, 30(1): 118-127, January

SMITH, G V. 1989. Amos: A Commentary. Grand Rapids : Zondervan

STUART, D 1987. Hosea- Jonah Waco: Word (WBC 31.)

TUCKER, G M., PETERSON, D L \& WILSON, R R eds. 1988 Canon, Theology and Old Testament Interpretation Essays in honor of Brevard S Childs. Philadelphia : Fortress

VAN DER WAL, A 1983. The Structure of Amos Journal for the Study of the Old Te'stament, 26:107-113.

VAN GELDEREN, C. 1933 Het boek Amos Kok: Kampen.

VAN LEEUWEN, C. 1985 Amos. Nijkerk: Callenbach. (POT)

WALTKE, B.K \& O'CONNOR, M 1990. An Introduction to Biblical Hebrew Syntax Eisenbrauns: Wiona Lake Indiana

WANKE, G. 1966 òj und hôj. Zeitschrift fuir die altestamentliche Wisssenschaft, 78(2) $215-218$

WEISER, A. 1974. Das Buch der zwölf kleinen Propheten I Gottingen : Vandenhoeck \& Ruprecht (ATD 24)

WITTENBERG, G.H. 1987. Amos 6: 1-7. Journal of Theology for Sowthern Africa, 58: 57 69

WOLFF, H.W 1964 Amos' geistige Heimat Neukirchen-Vluyn : Neurkirchener Verlag (WMANT 18)

WOLFF, H.W. 1975 Dodekapropheten 2 Joel und Amos Neukirchen-Vluyn : Neukirchener Verlag (BKAT XIV/2)

WOLFF, HW. 1977. Joel and Amos. Philadelphia : Fortress. (Hermeneia) 